\title{
Micropropagation through apical shoot explants and morphogenic potential of different explants of Saussurea lappa: An endangered medicinal plant
}

\author{
Zaib-Un-Nisa ${ }^{1}$, Samin Jan ${ }^{1}$, Muhammad Anwar Sajad ${ }^{1}$, Safdar Hussain \\ $\mathrm{Shah}^{2}$, Ghulam Farooq ${ }^{3}$ and Hazrat $\mathrm{Ali}^{4^{*}}$ \\ 1. Department of Botany, Islamia College Peshawar (ICP), Peshawar-Pakistan \\ 2. Institute of Biotechnology and Genetic Engineering (IBGE), Khyber Pakhtunkhwa Agriculture University, \\ Peshawar-Pakistan \\ 3. Department of Genetics, Hazara University, Mansehra-Pakistan \\ 4. Department of Zoology, University of Malakand, Chakdara 18800, Dir Lower-Pakistan \\ *Corresponding author's email: hazratali@uom.edu.pk \\ Citation \\ Zaib-Un-Nisa, Samin Jan, Muhammad Anwar Sajad, Safdar Hussain Shah, Ghulam Farooq and Hazrat Ali. \\ Micropropagation through apical shoot explants and morphogenic potential of different explants of Saussurea lappa: \\ An endangered medicinal plant. Pure and Applied Biology. Vol. 8, Issue 1, pp585-592. \\ http://dx.doi.org/10.19045/bspab.2018.700220
}

Received: 15/10/2018 Revised: 14/12/2018 Accepted: 18/12/2018

Online First: $29 / 12 / 2018$

\section{Abstract}

Saussurea lappa is a medicinal plant, which is used against a lot of diseases. Due to over exploitation for commercial and medicinal purposes, this plant is now endangered. Current study was carried out to develop a protocol for micropropagation and to determine morphogenic potential of different explants for callus induction of S. lappa, with the objective to develop plants in short time and large number. The explants were properly sterilized with $0.1 \%$ mercuric chloride for 1, 2 and 3 minutes. Maximum sterilization was observed with 3 minutes but decreased explants survival. However, $85 \%$ explants survived with 1-minute treatment. Benzyl amino purine and indolebutyric acid at $1.0 \mathrm{mg} \mathrm{L}^{-1}$ concentration produced $90 \%$ shoots and $93.66 \%$ roots respectively. Among the different explants, seedling and root explants were found more efficient in callus induction compared to other explants. Callus initiation occurred after 3 days of culturing of shoot and seedling followed by petiole (6 days) whereas lamina explants took 15-20 days. After 7 subsequent subcultures, the highest relative growth rate of 0.141 week $^{-1}$ of callus was noted in seedling explants followed by root 0.098 week $^{-1}$ and petiole 0.082 week $^{-1}$ whereas lamina showed significantly low relative growth rate of 0.016 week $^{-1}$. Tissue culture technique should be used for conservation of endangered medicinal plants such as Saussurea lappa.

Keywords: Callus induction; Explants; Micropropagation; Relative growth rate; Saussurea lappa; Sterilization

\section{Introduction}

Herbal drugs have been designed as medicines for the management of wide range of diseases since ancient times. Ancient written records of many civilizations including Egyptian, Roman and Chinese give 
strong evidence about the use of medicinal plants. In world health, medicinal floras have played a key role. Besides the immense developments observed in current medication in the modern era, plant foliage still contributes significantly to health care. Over human history, curiosity in medicines derived from higher plants has increased expressively, particularly in the phytotherapeutic ones [1].

Saussurea genus belongs to asteraceae family. The family has 300 species globally in which approximately 61 species exist in India [2]. In this genus, S. lappa is one of the well-known species. S. lappa roots and oils are used as an important drug. The over exploitation of $S$. lappa for diverse commercial and medicinal purposes greatly reduces the plant availability in its natural or wild habitat. This critically endangered medicinal plant ( $S$. lappa) is enlisted in endangered species of plants. S. lappa is one of the endangered plants out of 37 therapeutic plants of Himalayan region [3].

The in vitro direct production of plants from any explants, called micropropagation, is a well-organized technique which produces consistent, healthy, genetically stable, pesticides and disease-free seeds and plants throughout the year. Micropropagation has advantage over common conventional methods of propagation due to high rate of multiplication. Majority of the plants growing through seeds are greatly heterozygous and illustrate high variation in yield, growth, and habit. These may have to be discarded due to poor quality of products for their commercial release. Similarly, many plants are not amenable to propagate vegetative by means of cutting and grafting. Furthermore, majority of plants propagated by vegetative means have systemic bacteria, viruses and fungi [4]. Such techniques are usually used for plants which cannot be grown easily by conventional methods or used for conservation purposes of rare, unique and endangered medicinal plants [5, 6].

Medicinal plants which are propagated through tissue culture are genetically pure elite. Tissue culture techniques are essential for conservation of rare, threatened and endangered medicinal plants species within short time and limited space. The plants produced through such method are independent of soil and climatic conditions. Efforts have been devoted for in vitro mass multiplication of medicinally important endangered herbs [7]. The main objective of the current study is to determine the most suitable explants for callus induction and conserve genetically pure plants of S. lappa through tissue culture techniques.

\section{Materials and methods Surface sterilization}

Explants were excised from young seedling plants. Mercuric chloride solution of $1 \%$ was prepared using distilled water. Explants were treated for 1,2 and 3 minutes in three different experiments. After each treatment, the explants were washed 5 times with sterilized distilled water [8].

\section{Shoot multiplication and elongation}

Sterilized apical shoots from seedlings were excised aseptically and inoculated on MS full strength medium fortified with benzyl amino purine (BAP) at three different concentrations i.e., $0.20,0.50$ and $1.0 \mathrm{mg} \mathrm{L}^{-1}$ for shoot multiplication and elongation. However, control was kept without addition of BAP i.e., at $0 \mathrm{mg} \mathrm{L}^{-1}$. The $\mathrm{pH}$ of the medium was adjusted at 5.8 and solidified with $6 \mathrm{~g}$ of Agar gel [9]. Three different experiments with three different concentrations were conducted for shoot multiplication and elongation.

\section{Root induction from regenerated shoots}

The shoots after two weeks were transferred to rooting medium. The MS medium with $\mathrm{pH}$ 5.8 was supplemented with indole butyric acid (IBA) at three different concentrations 
i.e., $0.2,0.5$ and $1.0 \mathrm{mg} \mathrm{L}^{-1}$ for root induction and elongation [10].

\section{Maintaining inoculated explants}

The cultured test tubes were maintained in growth chamber at a regular cycle of 16 hours photoperiod of white cool fluorescent light and 8 hours dark at $25 \pm 2{ }^{\circ} \mathrm{C}$. For each treatment, three replicates were used. Observations were recorded for the percentage of explants producing shoots, roots, average number of shoots and roots per explants or per shoot, average number of root and shoot length after two weeks of inoculation [11].

\section{Growth measurements}

The plantlet shoot length and root length were measured in centimeters $(\mathrm{cm})$ according to Mikuła and Rybczyński [12] after 15 days of culturing.

\section{Acclimatization of micro-propagated plantlets}

Well rooted micro-propagated plantlets were detached from the test tubes and thoroughly washed under running tap water for 1-2 hours to remove all medium and agar traces attached to the roots. These plantlets were transferred to plastic pots containing autoclaved soil and compost at equal ratio (1:1). The pots were covered with transparent polythene bags to prevent evaporation and to facilitate light penetration. The pots were then acclimatized in the growth chamber at $25 \pm 2{ }^{\circ} \mathrm{C}$ temperature for three weeks. The pots were watered with distilled water at 6 days intervals. These bags were removed after three weeks and the plantlets were established successfully in field conditions[11].

Inoculation of different explants for callus induction

The root, petiole and lamina were excised from sterilized 15-20 days old micropropagated plant and 3 days old seedling were used as explants. The explants were picked up with the help of sterilized forceps and inoculated in $100 \mathrm{~mL}$ flasks containing MS medium fortified with 2.4-D+ Kinetin (Kin) at concentrations of $1 \mathrm{mg} \mathrm{L}^{-1}+0.25 \mathrm{mg}$ $\mathrm{L}^{-1}$. Medium without growth regulators was used as control for callus induction. Single explant was inoculated per flask. In order to get maximum sterilization, forceps were kept in ethanol and then burned with flame after every inoculation. The whole process of inoculation was carried out in closed proximity to the flame to diminish the chance of contamination. The cultured flasks were sealed tightly with aluminum foil and parafilm and labeled after inoculation. Afterwards the $100 \mathrm{~mL}$ flasks were placed in growth room, where the cultured flasks were kept under dark conditions. The flasks were monitored for contamination. Callus initiation of $S$. lappa seeds was observed daily. The effect of sterilization was observed as percentage of contamination free flasks containing medium and the days of callus induction were noted [12].

\section{Relative growth rate}

Callus was harvested after several subsequent sub-cultures. For the determination of the callus Relative Growth Rate (RGR), the method of Shah et al. [11] was used. Callus initial fresh weight and final fresh weight were recorded. The callus growth was expressed as relative growth rate week ${ }^{-1}$ using equation (A) as given below:

$\mathrm{RGR}=$ In (final weight of callus) - In (initial weight $) \div 2$ week $^{-1} \ldots$ (A)

\section{Results}

\section{Surface sterilization}

The data presented in (Table 1) indicate the percentage of $S$. lappa shoot sterilization after treatment with $0.1 \%$ aqueous $\mathrm{HgCl}_{2}$ solution for three different time periods. The data indicate that with increase in time, sterilization percentage increased but the chance of shoots survival decreased. Maximum sterilization percentage (92\%) was recorded with $\mathrm{HgCl}_{2}$ used for 3 minutes followed by 2 minutes ( $80 \%$ ) while minimum 
sterilization percentage $(65 \%)$ was found with 1-minute treatment. However, apical shoot explants survival chance was greater
$(85 \%)$ with 1-minute treatment followed by 2 minutes $(30 \%)$ while $95 \%$ explants burned when treated for 3 minutes; only $5 \%$ plants survived.

Table 1. Sterilization of Saussurea lappa shoot explants by $0.1 \% \mathrm{HgCl}_{2}$ solution

\begin{tabular}{|c|c|c|}
\hline Time (min) & Sterilization (\%) & \% survival of plants \\
\hline 1 & 65 & 85 \\
\hline 2 & 80 & 30 \\
\hline 3 & 92 & 5 \\
\hline
\end{tabular}

\section{Micropropagation}

\section{Shoot organogenesis}

The data regarding micropropagation and multiplication are presented in (Table 2). The apical shoot explants sterilized with $0.1 \%$ mercuric chloride for 1 minute responded better in terms of multiple shoot proliferation. These explants showed direct organogenesis when cultured on MS medium using different concentrations of BAP i.e., 0.2, 0.5, and 1.0 $\mathrm{mg} \mathrm{L}^{-1}$ for shoot proliferation. BAP at $1.0 \mathrm{mg}$ $\mathrm{L}^{-1}$ concentration showed maximum shoot induction than 0.50 and $0.20 \mathrm{mg} \mathrm{L}^{-1}$ concentrations. At this concentration, $100 \%$ explants responded and the number of shoots (5.0 \pm 0.57$)$ and length of shoot per explant $(2.9 \pm 0.25 \mathrm{~cm})$ were recorded. In comparison, $90 \%$ shoots were produced in medium supplemented with $0.50 \mathrm{mg} \mathrm{L}^{-1}$ BAP and the number of shoots and length of shoot per explants were recorded as $2.66 \pm 0.33$ and $3.8 \pm 0.11 \mathrm{~cm}$ respectively (Table 2). However, $0.20 \mathrm{mg} \mathrm{L}^{-1}$ concentration of BAP showed poor results. At this concentration, $56.0 \pm 5.2 \%$ explants produced shoots, number of shoots per explants were $1.33 \pm 0.57$ and shoot length was $1.66 \pm 0.57$ $\mathrm{cm}$. The best outcome was achieved using $1.0 \mathrm{mg} \mathrm{L}^{-1} \mathrm{BAP}$ in terms of shoot production and number of shoots compared to 0.20 and $0.50 \mathrm{mg} \mathrm{L}^{-1}$. However, the shoot length was highest at $0.50 \mathrm{mg} \mathrm{L}^{-1}$ concentration. The explants were subcultured after every 15 days of inoculation. In the control medium no shoot multiplication was observed.

Table 2. Effect of different concentrations of BAP on shoot organogenesis from explants

\begin{tabular}{|c|c|c|c|}
\hline BAP $\left(\mathbf{m g ~ L}^{-\mathbf{1}}\right)$ & $\begin{array}{c}\text { Explants producing } \\
\text { shoots }(\boldsymbol{\%})\end{array}$ & $\begin{array}{c}\text { No. of shoots per } \\
\text { explants }\end{array}$ & Shoot length (cm) \\
\hline 0.2 & $56.0 \pm 5.2$ & $1.33 \pm 0.57$ & $1.66 \pm 0.57$ \\
\hline 0.5 & $90.66 \pm 0.66$ & $2.66 \pm 0.33$ & $3.8 \pm 0.11$ \\
\hline 1.0 & $100 \pm 0$ & $5.0 \pm 0.57$ & $2.9 \pm 0.25$ \\
\hline
\end{tabular}

The data are mean of three replicates $\pm \mathrm{SE}$

\section{Root organogenesis}

In order to induce roots, the individual in vitro grown shoots were transferred to full strength MS media fortified with different concentrations of indole butyric acid (IBA) i.e., $0.2,0.5$ and $1.0 \mathrm{mg} \mathrm{L}^{-1}$. Without growth regulators, no root induction was observed.
The concentrations of the plant growth regulators used individually in these experiments induced rooting and the data are presented in (Table 3). In $0.5 \mathrm{mg} \mathrm{L}^{-1}$ IBA, $93.66 \pm 0.66 \%$ roots were produced while $100 \%$ shoots produced roots in the medium supplemented with $1.0 \quad \mathrm{mg}^{-1} \quad$ IBA. 
Maximum number $(6.4 \pm 0.18)$ and the longest $(6.56 \pm 0.06 \mathrm{~cm})$ roots were obtained with $1.0 \mathrm{mg} \mathrm{L}^{-1}$ concentration within two weeks of inoculation while in $0.5 \mathrm{mg} \mathrm{L}^{-1} \mathrm{IBA}$ supplemented medium, the corresponding values were $3.73 \pm 0.12$ and $5.58 \pm 0.06 \mathrm{~cm}$. However, $0.20 \mathrm{mg} \mathrm{L}^{-1}$ concentration showed poor results. At this concentration, $46.66 \pm$ $15.2 \%$ explants produced roots, roots per explant were $1.33 \pm 0.56$ and root length was $1.23 \pm 0.20 \mathrm{~cm}$. The plantlets in pots were kept covered by transparent polythene bags for hardening outside the growth chamber. After seven days, the bags were completely removed and $80 \%$ of the transplanted plants survived. Initially, the growth performance was slow after transplantation; afterward it improved gradually, and two weeks later new leaves began to emerge from the plants.

Table 3. Effect of different concentrations of IBA on root organogenesis of explants

\begin{tabular}{|c|c|c|c|}
\hline IBA $\left(\mathbf{m g ~ L}^{-\mathbf{1}}\right)$ & $\begin{array}{c}\text { Explants producing } \\
\text { roots }(\boldsymbol{\%})\end{array}$ & $\begin{array}{c}\text { No. of roots per } \\
\text { explant }\end{array}$ & Root length (cm) \\
\hline 0.2 & $46.66 \pm 15.2$ & $1.3 \pm 0.56$ & $1.23 \pm 0.20$ \\
\hline 0.5 & $93.66 \pm 0.66$ & $3.73 \pm 0.12$ & $5.58 \pm 0.06$ \\
\hline 1.0 & $100 \pm 0$ & $6.4 \pm 0.18$ & $6.56 \pm 0.06$ \\
\hline
\end{tabular}

The data are mean of three replicates \pm SE

\section{Callus induction from different parts of explants}

Changes occurred in explants after culturing as they became swollen and got thick. Callus initiation occurred in seedling explants, root explants and petiole explants after 3,4 and 5 days of culturing, respectively whereas lamina took $15-18$ days to initiate callus (Figure 1). The callus observed was soft, compact, globular and light green in case of petiole and root explants while white in seedling and lamina explants. After several subsequent subcultures, all explants derived calli were found white in color.

The highest RGR of 0.141 week $^{-1}$ of callus was noted in seedling explants followed by root $\left(0.098\right.$ week $\left.^{-1}\right)$ and petiole $(0.082$ week $^{-1}$ ) whereas lamina showed significantly low RGR of 0.016 week $^{-1}$ (Figure 2). Calli cultures were taken in triplicate for each experiment.

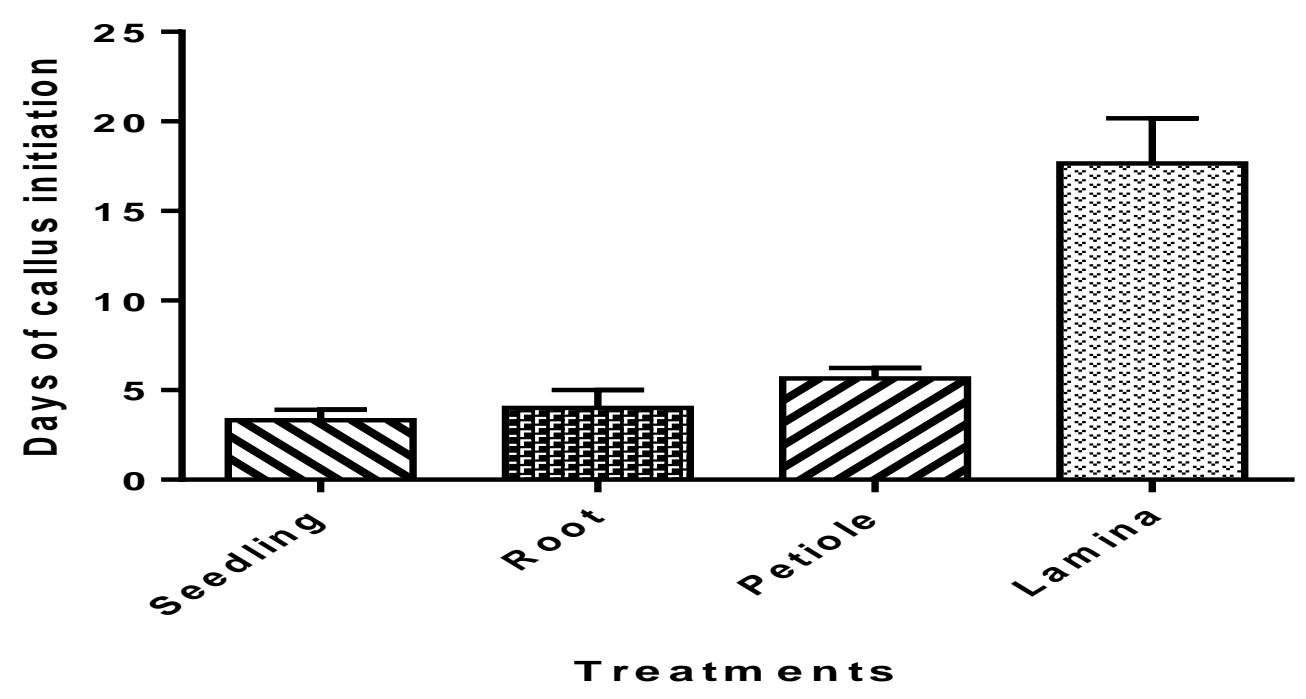


Figure 1. Number of days to initiate callus in different explants. Results are the means of three replicates \pm SD

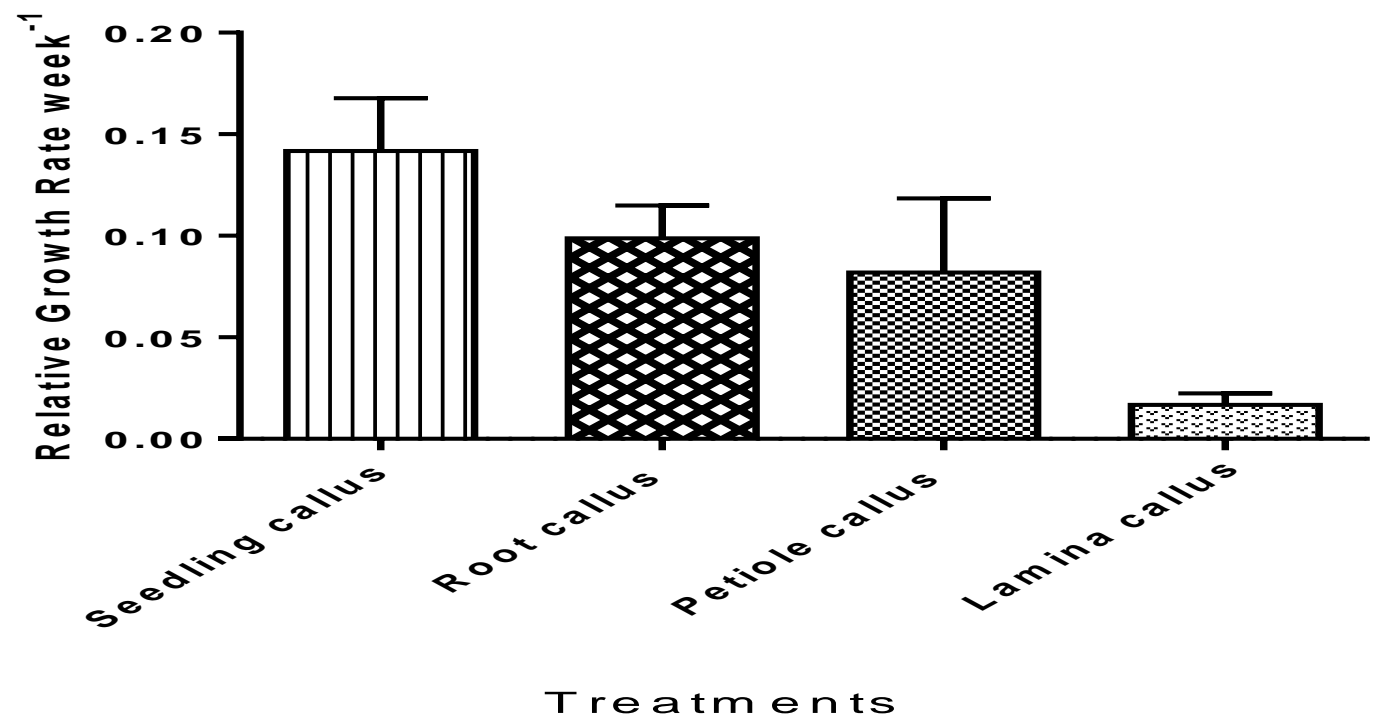

Figure 2. Relative Growth Rate (RGR) of different explants. Results are the means of three replicates \pm SD

\section{Discussion}

Apical shoots of S. lappa used as explants were found best for multiple shoot proliferation. Similar results have been reported in many other medicinal plants; apical shoot and nodes explants are frequently preferred for commercial micropropagation purposes due to their high potential of cell division [13]. BAP at $1 \mathrm{mg}$ $\mathrm{L}^{-1}$ concentration exhibited best response in respect of apical shoot production and multiplication compared to 0.2 and $0.5 \mathrm{mg} \mathrm{L}^{-1}$ concentration. IBA at $1 \mathrm{mg}$ $\mathrm{L}^{-1}$ concentration was found best in induction of rooting, number of roots and root length. Both the growth regulators BAP and IBA did not exhibit any adverse effects on the growth and development of the plant body. It is reported that auxin and cytokinin when used in proper concentrations stimulate root, shoot production and development. Similar reports have been published in other medicinal plants [14-16].

Regarding the morphogenic potential of different explants (seedling, lamina, petiole and root), S. lappa initiated callus production at the cut edges and covered the entire surface of explants after several subsequent subcultures. All the explants responded differently, significantly from each other, when cultured on same MS media supplemented with similar combination of growth regulators. In-vitro study shows that growth regulators induce callus formation by stimulating cell division, cell growth and DNA replication. The signaling networks of hormones influence the parameters of cell cycle and establish functional links between the cell cycle regulatory mechanisms and genes involved in formation of callus. Among various explants, seedling and root of seedling were found most efficient in callus induction. Our results show agreement with the previous findings [17-20]. Calli produced were very soft, compact, globular and light green in case of petiole and root explants while white from lamina explants at the beginning of the culture period and after several subcultures all calli turned whitish in 
color. These results show similarity with some other reports [21-23].

\section{Authors' contributions}

Conceived and designed the experiments: $S$ Jan \& SH Shah, Performed the experiments: ZU Nisa, Analyzed the data: ZU Nisa, G Farooq \& SH Shah, Contributed materials/analysis tools: SH Shah, Wrote the paper: ZU Nisa, MA Sajad \& H Ali.

\section{References}

1. Calixto JB (2000). Efficacy, safety, quality control, marketing and regulatory guidelines for herbal medicines (phytotherapeutic agents). Braz J Med Biol Res 33(2): 179-189.

2. Hajra PK, Rao RR, Singh DK \& Uniyal BP, Flora of India, 1995.

3. Kuniyal CP, Rawat YS, Oinam SS, Kuniyal JC \& Vishvakarma SCR (2005). Kuth (Saussurea lappa) cultivation in the cold desert environment of the Lahaul valley, northwestern Himalaya, India: arising threats and need to revive socio-economic values. Biodiver Conser 14(5): 1035-1045.

4. Murch SJ, Krishna RS \& Saxena PK (2000). Phyto-pharmaceuticals: mass production, standardization, and conservation. Sci Rev Alt Med 4: 39-43.

5. Parmessur Y, Aljanabi S, Saumtally S \& Dookun-Saumtally A (2002). Sugarcane yellow leaf virus and sugarcane yellows phytoplasma: elimination by tissue culture. Plant Pathol 51(5): 561-566.

6. Liao Z, Chen M, Tan F, Sun X \& Tang $\mathrm{K}$ (2004). Microprogagation of endangered Chinese aloe. Plant Cell Tissue Organ Culture 76(1): 83-86.

7. Yadav K, Singh N \& Verma S (2012). Plant tissue culture: a biotechnological tool for solving the problem of propagation of multipurpose endangered medicinal plants in India. $J$ Agricul Technol 8(1): 305-318.

8. Nisa Z, Samin J \& Safdar HS (2016). Standardization of protocol for the surface sterilization and callus induction of Saussurea lappa: an endangered medicinal plant. Int J Biosci 9(1): 324330.

9. Sharma N, Chandel KPS \& Paul A (1993). In vitro propagation of Gentiana kurroo - an indigenous threatened plant of medicinal importance. Plant Cell Tissue Organ Culture 34(3): 307-309.

10. Kaur R, Sadiq M, Kumar V, Mahajan R, Saxena B \& Sharma DR (2007). In vitro propagation and conservation of Gentiana kurroo-a temperate medicinal herb. J Plant Sci Res 23(1-2): 69-72.

11. Shah SH, Wainwright SJ \& Merrett MJ (1990). The interaction of sodium and calcium chlorides and light on growth, potassium nutrition, and proline accumulation in callus cultures of Medicago sativa L. New Phytol 116(1): 37-45.

12. Mikuła A \& Rybczyński JJ (2001). Somatic embryogenesis of Gentiana genus I. The effect of the preculture treatment and primary explant origin on somatic embryogenesis of Gentiana cruciata (L.), G. pannonica (Scop.), and G. tibetica (King). Acta Physiol Plant 23(1): 15-25.

13. Sultana S \& Handique PJ (2004). Micropropagation of Wedelia chinensis through high frequency shoot multiplication using nodal explants. $J$. Curr. Sci 5(447-452.

14. Martin K (2003). Rapid in vitro multiplication and ex vitro rooting of Rotula aquatica Lour a rare rhoeophytic woody medicinal plant. Plant Cell Rep 21(5): 415-420.

15. Joshi M \& Dhar U (2003). In vitro propagation of Saussurea obvallata (DC.) Edgew.-an endangered ethnoreligious medicinal herb of Himalaya. Plant Cell Rep 21(10): 933939. 
16. Roy PK (2008). Rapid multiplication of Boerhaavia diffusa L. through in vitro culture of shoot tip and nodal explants. Plant Tissue Culture Biotechnol 18(1): 49-56.

17. Hosokawa K, Nakano M, Oikawa Y \& Yamamura S (1996). Adventitious shoot regeneration from leaf, stem and root explants of commercial cultivars of Gentiana. Plant Cell Rep 15(8): 578581.

18. Abdel-Rahim EA, Abdel-Fatah OM, Kobasse MI, El-Shemy HA \& El-Samei MBA (1998). Growth of date palm callus as affected by growth regulators, sugars as carbon source and amino acids as organic nitrogen source. Arab $J$ Biotechnol 1(1): 99-106.

19. Sharan AK, Dubey SR, Singh BP, Kumar G \& Kumari S (2014). Diversity in callus organization in Eclipta alba Hassak. Int J Adv Res 2(7): 465-473.

20. Huang B, Han L, Li S \& Yan C (2015). Optimization of induction, subculture conditions, and growth kinetics of Angelica sinensis (Oliv.) Diels callus. Pharmacog Magaz 11(43): 574-578.

21. Monacelli B, Pasqua G, Cuteri A, Varusio A, Botta B \& Delle GM (1995). Histological study of callus formation and optimization of cell growth in Taxus baccata. Cytobios 81(326): 159-170.

22. Rao AQ, Hussain SS, Shahzad MS, Bokhari SYA, Raza MH, Rakha A, Majeed A, Shahid AA, Saleem Z, Husnain T \& Riazuddin S (2006). Somatic embryogenesis in wild relatives of cotton (Gossypium Spp.). J Zhejiang Uni Sci B 7(4): 291-298.

23. Purohit $P$, Bais RT, Singh $P$ \& Khan $S$ (2015). Comparative assessment of lupeol in wild plant and in vitro callus culture of Hemidesmus indicus by HPLC technique. UKJ Pharmaceut Biosci 3(1): 42-46. 